\title{
STRATEGI KOMUNIKASI DAKWAH KH ZAINUL MAA'RIF DALAM PEMANFAATAN MEDIA DAKWAH
}

\author{
COMMUNICATION STRATEGY OF DAKWAH KH ZAINUL MAA'RIF IN UTILIZING \\ MEDIA OF EDUCATION
}

\author{
Fitri Ummu Habibah \\ Fakultas Dakwah dan Komunikasi Universitas Islam Negeri Walisongo Semarang \\ Jl. Kesejahteraan Sosial No.1 Sonosewu Ngestiharjo Kasihan Bantul Yogyakarta \\ email:fitriummuhabibah464@gmail.com; HP:081476631663 \\ Diterima: 22 Juni 2019, Direvisi: 15 Juli 2019, Disetujui: 24 Juli 2019
}

\begin{abstract}
ABSTRAK
Dakwah merupakan proses penyampaian atau cara-cara tertentu yang dilakukan seorang da'i kepada mad'u untuk mencapai suatu tujuan atas dasar hikmah dan kasih sayang. Pada saat ini banyak da'i yang muncul di tengah-tengah masyarakat, menyampaikan dakwahnya dengan metodemetode khusus sehingga menarik perhatian masyarakat. Dari sekian banyak da'i yang mampu membuat mad'u terkesima akan gaya bicaranya yang khas saat menyampaikan materi dakwahnya adalah KH. Yahya Zainul Ma'arif (selanjutnya disebut Buya Yahya). Dia adalah seorang yang memiliki sifat ramah, hal itu dapat dilihat dari mimik wajahnya dalam setiap menyampaikan dakwahnya dan sikapnya yang tampak ketika berinteraksi secara langsung dengan para jamaah. Penelitian ini merupakan penelitian subjek dan aktivitas dakwah. Tujuan penelitian adalah untuk mengetahui metode dakwah KH. Yahya Zainul Ma'arif. Jenis penelitian adalah kualitatif studi tokoh dengan spesifikasi analisis taksonomi. Desain analisis taksonomi yaitu dengan memaparkan domain subjek penelitian dan segala aspek yang membentuk perannya dalam bidang dakwah Islam. Hasil penelitian menunjukkan bahwa metode dakwah yang digunakan oleh KH. Yahya Zainul Ma'arif adalah metode tabligh. Tabligh tersebut dilakukan dengan cara membentuk majelis ceramah. Setelah tabligh dilakukan, Buya Yahya mengembangkan tabligh dengan melakukan pengkaderan. Pengkaderan tersebut dilakukan dengan cara tarbiyah, dari tarbiyah inilah akan muncul ulama' yang akan melanjutkan misi dakwah ke depannya. Oleh karena itu, Buya Yahya mendirikan Pondok Pesantren Lembaga Pengembangan Dakwah (LPD) al Bahjah. Sebenarnya dalam aktivitas tabligh, Buya Yahya sambil menggali potensi untuk mengajak bersama-sama melakukan tabligh. Dalam bertabligh juga menggunakan berbagai media, seperti sound system dan media-media lain, seperti radio, TV, live streaming, facebook, instagram, aplikasi android (buya Yahya di playstore) dan web agar tabligh tersebut sampai ke masyarakat luas. Metode tabligh tersebut mencakup empat hal, yaitu al hikmah, mauidzah al hasanah dan mujadalah dan tanya jawab.
\end{abstract}

Kata-kata kunci: dakwah KH Yahya Zainul Maa'rif; metode dakwah;tabligh; media komunikasi

\section{ABSTRACT}

Da'wah is a process of delivering or certain ways that a da'i tells mad'u to achieve a goal on the basis of wisdom and compassion. At this time many da'i appeared in the midst of society, conveying their da'wah with special methods so as to attract the attention of the public. Of the many 
da'i who were able to make mad'u amazed at his distinctive style of speech when delivering his da'wah material was KH. Yahya Zainul Ma'arif (hereinafter referred to as Buya Yahya). He is a person who has a friendly nature, it can be seen from the look on his face in each conveying his preaching and his attitude that appears when interacting directly with the worshipers. This research is a subject research and missionary activity. The purpose of the study was to find out the method of da'wah KH. Yahya Zainul Ma'arif. This type of research is a character qualitative study with taxonomic analysis specifications. The design of taxonomic analysis is to describe the subject domain of research and all aspects that shape its role in the field of Islamic da'wah. The results of the study showed that the da'wah method used by KH. Yahya Zainul Ma'arif is a tabligh method. Tabligh is done by forming a lecture assembly. After the tabligh was conducted, Buya Yahya developed tabligh by doing cadre. The cadre was carried out by means of tarbiyah from this tarbiyah. Ulama will emerge who will continue the missionary mission in the future. Therefore, Buya Yahya founded the Islamic Boarding School Islamic Boarding School (LPD) al Bahjah. Actually in tabligh activity, Buya Yahya explores the potential to invite tabligh together. In bertabligh also uses a variety of media, such as sound systems and other media, such as radio, TV, live streaming, facebook, Instagram, android applications (Buya Yahya in the playstore) and the web so that the tabligh reaches the wider community. The tabligh method includes four things, namely al hikmah, mauidzah al hasanah and mujadalah and question and answer.

Keywords: preaching KH Yahya Zainul Maa'rif; methods of da'wah; tabligh; communication media

\section{PENDAHULUAN}

Dakwah pada hakekatnya adalah segala aktifitas dan kegiatan yang mengajak orang untuk berubah dari situasi yang mengandung nilai kehidupan yang bukan Islami kepada nilai kehidupan yang Islami. Aktifitas dan kegiatan itu dilakukan dengan mengajak, mendorong, menyeru, tanpa tekanan, paksaan dan provokasi. Dakwah merupakan ajakan yang tujuannya dapat tercapai hanya dengan persetujuan tanpa paksaan dari obyek dakwah (Suparta ed. 2003: 31-32). Aktifitas dakwah dalam Islam merupakan proses penyampaian ajaran agama Islam terhadap umat manusia disetiap ruang dan waktu dengan berbagai metode dan media yang sesuai dengan situasi dan kondisi para penerima (mad'u) dakwah tersebut (Enjang \& Aliyuddin, 2009: 145). Jika dianalisa keseluruhan terhadap sebuah proses dakwah, maka dapat dilihat bahwa pentingnya keselarasan antara metode dakwah dengan tujuan dakwah. Pentingnya metode dakwah juga memperlihatkan bahwa tata cara dalam berdakwah lebih penting dari materi dakwah itu sendiri. Betapapun sempurnanya materi dakwah tetapi bila disampaikan dengan cara yang kurang tepat dan tidak sistematis akan menimbulkan hasil yang tidak sesuai. Sebaliknya, jika materi dakwah sederhana, namun disampaikan dengan cara menarik dan dapat menyentuh hati pendengarnya, maka akan menimbulkan kesan yang mendalam bagi mad'u. Dakwah haruslah dikemas dengan metode yang tepat dan sesuai dengan materi yang disampaikan. Dakwah harus disampaikan secara aktual, faktual, dan kontekstual. Aktual dalam arti konkrit memecahkan masalah yang sedang terjadi dan hangat ditengah masyarakat. Faktual dalam arti konkrit dan nyata. Kontekstual dalam arti relevan dan menyangkut problematika yang sedang dihadapi masyarakat (al Haddad, 2001: $55)$.

Ma'arif (1990: 2) menjelaskan beberapa faktor yang dapat menyebabkan berhasil atau tidak seorang da'i dalam mempengaruhi mad'u, yaitu: petama, pesan dakwah yang disampaikan oleh 
seorang da'i relevan dengan kebutuhan masyarakat. Kedua, penampilan seorang da'i memiliki daya tarik personal yang menyebabkan masyarakat mudah menerima pesan dakwahnya, walaupun kualitas dakwahnya sederhana. Ketiga, kondisi psikologi masyarakat yang membutuhkan siraman rohani serta persepsi yang positif kepada seorang da'i, sehingga pesan dakwah yang sebenarnya kurang jelas ditafsirkan sendiri oleh masyarakat dengan penafsiran yang jelas. Keempat, kemasan yang menarik menjadikan masyarakat yang semula acuh tak acuh terhadap agama dan juga terhadap da'i setalah melihat kemasan lain misalnya: kesenian, stimulasi, ataupun program pengembangan masyarakat maka paket dakwah menjadi stimulasi yang baik untuk masyarakat dan akhirnya mereka merespon secara positif. Oleh karena itu, untuk melakukan kegiatan dakwah, maka diperlukan metode-metode yang representatif dengan menggunakan bahasa yang lugas, menarik, bijaksana sehingga komunikasi menjadi menarik, sebagaimana Fiman Allah SWT dalam QS. al Nahl ayat 125 yang artinya "Serulah (manusia) kepada jalan Tuhanmu dengan hikmah dan pelajaran yang baik dan bantahlah mereka dengan cara yang baik. Sesungguhnya Tuhanmu Dialah yang lebih mengetahui tentang siapa yang tersesat dari jalan-Nya dan Dialah yang lebih mengetahui orang-orang yang mendapat petunjuk"

Metode dakwah merupakan
proses penyampaian atau cara-cara tertentu yang dilakukan seorang da'i kepada mad'u untuk mencapai suatu tujuan atas dasar hikmah dan kasih sayang. Metode juga merupakan cara dakwah seorang da'i kepada mad'unya dalam menyampaikan materi. Pada saat ini para da'i yang muncul di tengah-tengah masyarakat, yang menyampaikan dakwahnya dengan metode khusus sehingga menarik perhatian masyarakat. Seorang da'i dituntut untuk bisa merangkai katakata yang dapat dipahami oleh para mad'u, walaupun pada dasarnya sering kali para da'I menyampaikan ayat ataupun hadits yang sama namun disitulah kreativitas seorang da'i diuji agar dapat menyampaikan pesan dakwah dengan ciri khas mereka dan dapat dipahami oleh para mad'u. Dari sekian banyak da'i yang mampu membuat mad'u terkesima akan gaya bicaranya yang khas saat menyampaikan materi dakwahnya, adalah $\mathrm{KH}$. Yahya Zainul Ma'arif (selanjutnya disebut Buya Yahya). Dia adalah seorang yang memiliki sifat ramah, hal itu dapat dilihat dari mimik wajahnya dalam setiap menyampaikan dakwahnya dan sikapnya yang tampak ketika berinteraksi secara langsung dengan para jamaah. Buya Yahya lahir di Blitar, yang sekarang bertempat tinggal di Kabupaten Cirebon, Kelurahan Sendang. Buya Yahya melanjutkan pendidikannya ke Univesitas al Ahgaff di Yaman, selama di Yaman Buya Yahya mengambil beberapa disiplin ilmu diantaranya Fiqih, Aqidah, Ulum al Qur'an dan Musthalah al Hadits. Buya Yahya sempat mengajar di Fakultas Tarbiyah dan Dirasah Islamiyah (khusus putri) Univesitas al Ahgaff Yaman selama empat tahun. Kedatangan Buya Yahya ke Cirebon pada akhir tahun 2005 dalam rangka menjalankan tugas dari gurunya untuk memimpin pesantren. Seiring perjalanan waktu Buya Yahya merasakan kenyamanan di Cirebon, kemudian Buya Yahya meminta izin kepada gurunya untuk mengajar dan mendirikan sebuah pesantren di Cirebon yaitu Lembaga Pengembangan Dakwah (LPD) al Bahjah. Kurang lebih tujuh tahun Buya Yahya berdakwah, ia telah bisa berdakwah dengan majelis taklim yang diasuhnya secara rutin di berbagai tempat, diantaranya; Cirebon, Indramayu, Tangerang, Tulungagung, Pekanbaru, Batam, Hongkong, Malaysia, dan 
sebagainya (Dokumentasi Profil K.H. Yahya Zainul Ma'arif di LPD Al- Bahjah Cirebon, diakses pada 10 Apil 2017). Kegiatan rutinan inilah yang tidak banyak ditekuni para da'i, sebab da'i seringkali mengutamakan undangan pengajian. Perjalanan dakwah yang dilakukan Buya Yahya tentunya tidak lepas dari metode dakwah yang digunakan Buya.

Berdasarkan sekilas terhadap autobiografinya KH Yahya Zainul Maarif tersebut diatas maka dapat diambil segmentasi masalah penelitian ini tentang bagaimana strategi dakwah yang di kembangkan oleh Kh Yahya Zainul Maarif pada era sekarang ini yang cenderung banyak memanfaatkan media komunikasi digital.

\section{METODE}

Dalam metode penelitian yang dilakukan oleh penulis menggunakan jenis penelitian kualitatif yakni penelitian yang dilakukan untuk memahami fenomena tentang apa yang dialami oleh subjek penelitian misalnya perilaku, persepsi, motivasi, tindakan dan lain-lain (Moleong, 2009: 6). Apabila dilihat dari objeknya penelitian ini termasuk penelitian lapangan atau field research, yaitu kegiatan penelitian yang dilakukan di lingkungan masyarakat tertentu baik di lembagalembaga organisasi masyarakat (sosial) maupun lembaga pemerintahan (Suryabrata, 1998: 22). Adapun spesifikasi penelitian ini menggunakan model biografi atau studi tokoh. Yaitu studi terhadap seseorang atau individu yang dituliskan, tentang kehidupan seseorang yang melukiskan momen penting yang terjadi. Penelitian model biografi ini subjek penelitiannya dapat berupa orang yang masih hidup atau pula orang yang sudah meninggal dunia. sepanjang peneliti dapat memperoleh data atau dokumen relevan (Herdiansyah, 2012: 64-65). Jenis penelitian mengenai komunikasi dakwah yang digunakan oleh KH. Yahya Zainal Ma'arif. fokus kajian menganalisis komunikasi dakwah yam dilakukannya melalui penggunaan media sebagai salah satu sarana dakwah.

\section{HASIL}

Studi tokoh atau sering disebut juga dengan penelitian tokoh atau penelitian riwayat hidup individu (individual life history) merupakan salah satu jenis penelitian kualitatif yang sering digunakan untuk menyelesaikan salah satu tugas akhir. Studi tokoh diperkenalkan oleh ilmuwan barat. Namun, model penelitian ini diperkenalkan pada tahun 90-an di Indonesia. Model Ini hanya populer untuk kalangan lembaga pendidikan agama dan kurang populer di kalangan perguruan tinggi umum. Namun, dalam pelaksanaanya terdapat kendala metodologis, karena tidak ada suatu rujukan yang dapat dijadikan suatu pegangan dalam pelaksanaan studi di lapangan. Akibatnya, penelitian dilakukan apa adanya, tanpa merujuk pada bukubuku penelitian yang ada, tanpa mempertimbangkan karakteristik studi dan relevansinya, sehingga sering terjadi kerancuan dalam membangun kerangka metodologisnya (Furchan dan Maimun, 2005: 1).

Secara historis, model ini sudah lama digunakan orang. Pada zaman dahulu, metode ini pernah dipergunakan oleh sejarawan Yunani kuno, dan juga sejarawan Islam seperti Ibnu Khaldun. Pada mulanya karya-karya mengenai tokoh ini lebih banyak bersifat karya sastra dan lebih menekankan pada segi keindahan bahasa dalam penulisannya sehingga lebih enak dibaca dan lebik komunikatif. Namun, dalam perkembangannya, studi tokoh ini kemudian diadopsi oleh lembaga pendidikan tinggi dan diwujudkan dalam karya ilmiah untuk tugas akhir mahasiswa. Karena merupakan 
karya ilmiah, studi tokoh ini kemudian dibingkai dengan nilai-nilai ilmiah berupa kajian metodologis dan akademis yang bisa dipertanggungjawabkan secara ilmiah. Dilihat dari segi relevansinya dengan masyarakat, studi tokoh ini mempunyai pengaruh yang signifikan dalam aktivitas kehidupan masyarakat. Oleh karena itu, studi tokoh ini kemudian dikembangkan secara lebih luas di perguruan tinggi (Furchan dan Maimun, 2005: 6).

Menurut Kerlinger dalam Hadi (1996) penelitian adalah proses penemuan yang mempunyai karakteristik sistematis, terkontrol, empiris, dan mendasarkan pada teori dan hipotesis atau jawaban sementara. Sedangkan menurut Tuckman penelitian adalah suatu usaha yang sistematis untuk menemukan jawaban ilmiah terhadap suatu masalah, sistematis artinya mengikuti prosedur atau langkahlangkah tertentu. Selain itu penelitian didefinisikan sebagai: "Suatu usaha untuk menemukan, mengembangkan, dan menguji kebenaran suatu pengetahuan, dan usaha-usaha itu dilakukan dengan metode ilmiah". Sedangkan pengertian tokoh adalah seseorang yang terkemuka atau kenamaan dibidangnya, atau seseorang yang memegang peranan penting dalam suatu bidang atau aspek kehidupan tertentu dalam masyarakat. Seseorang tersebut berasal, dibesarkan, dan hidup dalam lingkungan masyarakat tertentu (Syafa'at, 2009).

Dari pengertian di muka disimpulkan bahwa penelitian studi tokoh adalah usaha untuk menemukan, mengembangkan, mengumpulkan data dan informasi tentang tokoh secara sistematik guna untuk meningkatkan atau menghasilkan informasi dan pengetahuan. Studi tokoh yang ada selama ini dilakukan dalam dua bentuk. Pertama, sebagai bagian dari pendekatan sejarah (historical approach) yang bersangkutan. Kedua, studi ini dikelompokkan pada bidang yang dibicarakan oleh tokoh yang bersangkutan. Misalnya, jika seorang tokoh membicarakan tasawuf, maka studi ini dimasukkan pada pendekatan tasawuf. Pengelompokan ini, ternyata mengalami kesulitan dalam penanganannya, sebab suatu studi tokoh memerlukan suatu analisis tersendiri yang tidak tercover dalam bidang ilmu yang digunakannya (Harahap, 2011: 4).

Tujuan studi ini pada umumnya adalah untuk mencapai suatu pemahaman tentang ketokohan individu dalam komunitas tertentu, melalui pandangannya yang mencerminkan pandangan warga dalam komunitas yang bersangkutan. Tujuan lain adalah untuk memperdalam pengertian kita terhadap komunitas tertentu di mana tokoh atau individu itu hidup. Melalui pengakuan yang berupa riwayat hidup ini, seorang individu akan banyak motivasi, aspirasi, dan ambisinya tentang kehidupan dalam masyarakatnya. Wawancara, dalam bentuk meminta seseorang untuk menceritakan riwayat hidupnya adalah metode yang paling mudah diperoleh. Hal ini karena orang pada umumnya senang sekali menceritakan kisah mengenai dirinya sendiri. Sudah barang tentu, ada juga individu yang menolak untuk mengungkapkan riwayat hidupnya. Biasanya ia mengalami hambatan psikologis untuk mengungkapkan kisah hidupnya. Misalnya, karena masa lalunya dianggapnya kurang baik atau karena ia tidak melihat keluarbiasaan dalam jalan hidupnya. Namun biasanya, setelah melalui pendekatan-pendekatan sehingga timbul hubungan pribadi yang baik dan dekat Danandjaja (1988: 114).

Buya Yahya (Yahya Zainul Ma'arif) lahir di Blitar dari 3 bersaudara. Saat ini Buya Yahya dan keluarga bertempat tinggal di Kompleks LPD Al Bahjah Jl. Pangeran Cakrabuana No. 179 Blok Gudang Air Kel. Sendang Kec. 
Sumber Cirebon. Kedatangan Buya Yahya Zainul Maarif (yang lebih akrab disapa Buya Yahya) ke Cirebon pada akhir tahun 2005 dalam rangka menjalankan tugas dari gurunya Rektor Universitas al Ahgaff al Murobbi Profesor al Habib Abdullah bin Muhammad Baharun (seorang guru yang sangat berpengaruh didalam perjalanan ilmiah Buya Yahya) untuk memimpin Pesantren Persiapan bagi mahasiswa sebelum kuliah ke Universitas al Ahgaff di Yaman.

Pada pertengahan 2006 Buya Yahya menghadap gurunya di Yaman dan diizinkan untuk berdakwah di masyarakat. Buya Yahya memulai berdakwah dari hal yang kecil, tidak memaksa dan apa adanya. Dengan penuh kesabaran Buya Yahya memasuki musholla kecil hingga akhirnya di mudahkan oleh Allah untuk membuka majelis taklim di Masjid besar, baik di Kota Cirebon atau di kota-kota yang lainnya. Majelis yang Buya Yahya diberi al Bahjah sekaligus nama pesantren yang saat ini telah dirintis. Sebelum ke Yaman, pendidikan dasar hingga SMP diselesaikan di kota kelahirannya. Pendidikan agama diambil di Madrasah Diniyah yang dipimpin oleh seorang guru yang sholeh al Murobbi KH. Imron Mahbub dari Blitar. Setelah itu melanjutkan pendidikannya ke Pondok Pesantren Darullughoh Wad Da'wah Bangil Pasuruan Jawa Timur di bawah asuhan Al- Murobbi Al-Habib Hasan bin Ahmad Baharun yaitu pada tahun 1988 hingga 1993. Pada tahun 1993 hingga 1996 mengajar di Pesantren Darullughah wa Da'wah sebagai masa hidmahnya kepada guru dan pesantren tempat dia pernah menimba ilmu. Pada tahun 1996 berangkat ke Universitas al Ahgaf atas perintah sang guru Habib Hasan Baharun hingga akhir 2005. Buya Yahya selama 9 tahun di Yaman belajar fiqih diantaranya kepada para Mufti Hadramaut Syekh Fadhol Bafadhol, Syekh Muhammad Al
Khotib, Syekh Muhammad Baudhon, dan Habib Ali Masyur bin Hafid. Selama di Yaman, dia juga belajar Ilmu Hadits diantaranya kepada DR. Ismail Kadhim al Aisawi dari Iraq dan Habib Salim Asysyathri.

Dari Habib Salim Asysyatiri Buya Yahya sempat mengambil beberapa disiplin ilmu diantaranya fiqih, aqidah, ulum al Qur'an dan musthalah al hadits. Buya Yahya tidak tinggal dipesantren (Rubath) Habib Salim Asysyathri Buya Yahya mendapatkan kesempatan yang sangat banyak untuk belajar darinya. Sebab dipagi hari Habib Salim mengajar di kampus dan sore hari hingga malam Buya Yahya mendapatkan waktu khusus selama hampir 2 tahun untuk belajar darinya 4 kali dalam seminggu mulai ashar hingga isya di Rubath Tarim. Hadits dan ilmu haditsnya di ambil dari beberapa guru diantaranya adalah Dr. Ismail Kadhim al Aisawi dan Secara khusus Ilmu ushul fiqihnya dia ambil dari beberapa pakarnya diantaranya; Syeh Muhammad Al-Hafid Assyingqithi, Syeh Muhammad Amin Assyinqiti dan Syeh Abdullah Walad Aslam Assyinqiti (semuanya adalah dari Syinqiti-Mortania yang mereka adalah para ulama dalam madhab maliki) dan DR. Mahmud Assulaimani dari Mesir. Ilmu bahasa Arabnya di ambil dari Syekh Muhammad Alhafid Assyinqiti, dengan kitab terakhir yang dikaji adalah Thurah Uqud al Juman dalam ilmu balaghah, Thurah Lami'ah al Af'al dalam ilmu sharaf dan Thurah Alfiyah Ibnu Malik dalam ilmu nahwu yaitu Alfiyah Ibnu Malik dengan tambahannya menjadi 2800 bait. Ilmu fiqih perbandingan dia ambil diantaranya dari Prof. DR. Ahmad Ali Toha Arroyyan dari Mesir seorang Alim dari mazhab maliki. Buya Yahya sempat mengajar di Yaman selama 4 tahun di Fakultas Tarbiyah dan Dirosah Islamiyah (khusus putri) Universitas Al Ahqaf. Sekarang Buya Yahya aktif berdakwah di 
masyarakat dan mengasuh pondok pesantren Al Bahjah yang berpusat di Kabupaten Cirebon, Jawa Barat dan juga aktif mengayomi majelis-majelis $\mathrm{Al}$ Bahjah yang tersebar ke penjuru Nusantara dan luar negeri. Selain itu ada kesibukan yang sangat diperhatikan yaitu kegiatan Buya Yahya dengan para santri di pondok pesantren.

\section{PEMBAHASAN}

\section{Dakwah sebagai Aktivitas Komunikasi KH Yahya Zainul Maarif}

Buya Yahya merupakan sosok yang bersahaja santun dalam bertutur dan bersikap serta mudah berinteraksi di masyarakat. Oleh karena itu, dimana dia masih nyantri, dia memegang amanah utuk bertanggung jawab dalam mengatur dan mengurusi santri dibagian keagamaan. Dari hal-hal kecil tersebut dia mulai memahami dan belajar banyak tentang organisasi. Buya Yahya adalah seseorang yang aktif di berbagai organisasi, baik organisasi yang ada dalam intansi pemerintahan seperti rukun tetangga (RT) dan rukun warga (RW), maupun organisasi kemasyarakatan seperti remaja masjid dan paguyuban. Dia juga belajar bagaimana berorganisasi dengan baik dan bagaimana mengelola organisasi tersebut dengan semaksimal mungkin. Pada akhirnya ide dan gagasan, ataupun hasil pemikirannya banyak diterima oleh rekan seperjuangan dan lingkungan masyarakat. Sebagaimana pemahaman Buya Yahya tentang dakwah bahwa dakwah dalam makna mengajak diri dan orang lain kepada kebaikan dan menjauhkan diri dan orang lain dari kemunkaran, boleh dilakukan oleh siapa saja yang merupakan ummat Rasulullah Saw. Siapapun kita baik yang kaya atau miskin, yang pandai maupun yang bodoh selagi umat Rasulullah Saw dia harus ikut berperan aktif dalam program mengajak kepada kebaikan dan menjauhi kemunkaran.
Upaya mengimbagi arus teknologi informasi kehidupan modern yang dirasa semakin jauh dari nilai-nilai ke-Islaman. Buya Yahya berupaya menghadirkan risalah Rasulullah sebagai penjelasan ditengah-tengah masyarakat, sebagai upaya pencapaian status khaira ummah Buya Yahya bersama al Bahjah menghadirkan portal dakwah yang diharapkan dapat menembus sekat pemisah ruang dan waktu yang beralamatkan di www.buyayahya.org.

Seperti media dakwah pada umumnya, konten www.buyayahya.org tidaklah memiliki perbedaan yang mencolok dengan portal dakwah yang lain. Dimana pengunjung akan disuguhi materi kajian ringan baik tasawuf maupun fiqih serta pemecahan problematika kehidupan sehari-hari, portal buyayahya.org juga menyediakan ruang diskusi tanya-jawab ditambah jadwal majelis taklim yang menurut informasi Buya Yahya mengasuh 29 majelis ta'lim dalam sebulan di daerah Cirebon dan sekitarnya. Selain memanfaatkan media internet, Buya Yahya juga memanfaatkan media radio untuk menyebarkan dakwah di tengah-tengah masyarakat. Buya Yahya juga aktif berdakwah melalui media sosial seperti Youtube yang bisa dikunjungi di channel Buya Yahya, Instagram dengan nama akun buyayahya_albahjah dan Facebook dengan nama akun Buya Yahya.

Diantara jadwal majelis Buya Yahya adalah sebagai berikut: a) Kajian Kitab Bidayatul Hidayah Karya Imam Al Ghozali; Senin malam selasa Pk. 20.0021.30 WIB; tempat Masjid Raya At taqwa Alun-alun Kota Cirebon. b) Tausiah Umum; Selasa Minggu ke 2 (20.00- 21.30) Masjid Agung Sumber Jl. Sunan kalijaga Komplek Pemda Kab Cirebon. c) Kajian Kitab Adabu Sulukil Murid Karya Imam Abdullah Bin Alwi Al Haddad; Sabtu malam minggu Pk. 20.00-21.30 Wib Masjid Raya Al Mustaqim Weru Kab 
Cirebon. d) Tausiah Umum (Program Mutiara Dakwah); Jumat 05.00-06.00 Radio RRI Pro1 Cirebon. e) Majelis Al Bahjah; Sabtu 06.30-07.30 Majelis Al Bahjah Jl. Raya Sendang (Belakang SDN 1 Sendang). f) Tausiah Umum (Program Da'i); Sabtu 16.00-17.30 Wib Radio Db Fm Cirebon. Sedangkan jadwal on air atau yang bersifat langsung adalah sebagai berikut : a) Live Masjid Attaqwa Cirebon; Kajian Kitab Bidayatul Hidayah ( Imam Al Ghazali ); Senin Malam Selasa Pkl 20.00 s/d 21.30 WIB. b) Live Masjid Al Mustaqim Cirebon; Kajian Kitab Adabus Sulukil Murid (Imam Al Haddad); Sabtu Malam Minggu Pkl. 20.00 s/d 21.30 WIB. c) Live Majelis Al Bahjah; Sabtu Pagi Pk.06.30 s/d 07.30WIB. d) Forum Komunikasi Dakwah; Minggu Pagi Pkl. 06.30 s/d 07.30 WIB. e) Live RASFM Jakarta; Setiap Rabu Minggu 1 \& 3.

Buya Yahya juga aktif dalam aktivitas dakwah di media televisi baik swasta, nasional maupun lokal, seperti di a) MNC TV setiap senin pagi pkl. 05.00 06.00 WIB, b) TV9 Surabaya setiap ahad pagi pkl. 05.00 - 06.00 WIB c) BBS TV Kediri setiap hari pkl. 16.00 - 17.00 WIB d) Radar Cirebon TV setiap hari kamis malam Jum'at pkl. 19.00 - 20.00 WIB e) Cirebon TV setiap hari kamis malam Jum'at pkl. 20.30 - 22.00 WIB; Hidup Indah Bersama Buya Yahya f) Batam TV Kabel Channel 1 setiap hari pkl. 05.00 $06.00 \& 18.00$ - 19.00 WIB.

\section{Strategi Dakwah dan Pemanfaatan Media Dakwah}

Dalam melaksanakan ajaran-ajaran dakwah Islam kepada masyarakat, jalannya tidak selamanya akan lurus, karena hambatan-hambatan pasti ada, baik dari da'i, mad'u ataupun materinya. Maka dari itu perlu metode yang tepat yang sesuai dengan situasi dan kondisi supaya dakwah bisa berhasil. Apabila cara, pelaksanaan dan metode yang digunakan sesuai dengan situasi masyarakat itu sendiri, maka senantiasa dakwah bisa diterima oleh masyarakat.

Seorang da'i bukan hanya mempunyai tugas menyampaikan saja, namun lebih dari itu, mulai dari tanggung jawab moral dan juga perkembangan Islam itu sendiri. Dakwah bukanlah mainan tapi sebuah amanah besar, jadi dakwah itu harus terkonsep secara jelas dan baik. Banyak aspek yang harus dipahami dan dimengerti oleh seorang da'I agar dakwah itu benar-benar tersampaikan tanpa ada kesalahan.

Da'i yang terbilang sukses dan professional bagi Buya Yahya adalah da'i yang berdakwah bukan hanya pada ceramah saja melainkan dakwah melalui berbagai hal. Seorang da'i harus menjadi contoh untuk mad'u atau jamaahnya. Suksesnya seorang da'i adalah seberapa besar mad'u memahami dan menerapkan apa yang disampaikan oleh da'i itu sendiri. Dalam berdakwah seorang da'i dituntut agar memahami betul apa yang dinginkan dan dibutuhkan oleh mad'u, agar dakwah yang disampaikan benar-benar sampai, sehingga dapat mengubah jalan pikiran orang lain kedalam perbuatan yang lebih baik sesuai dengan ajaran Islam. Seorang da'i juga harus memberikan suri tauladan yang baik kepada mad'u tentang ibadah dan muamalah dalam praktek kehidupan sehari-hari dimasyarakat.

Pada dasarnya antara dakwah dengan ilmu dan dakwah dengan harta sama, yaitu mereka berdakwah dengan dirinya sendiri. Dengan ilmu yang dia sampaikan dengan niat menunjukkan jalan kepada Allah. Begitu pula dengan harta, seseorang yang mendermakan hartanya di jalan Allah, berarti dia menju ke jalan Allah. Tujuan dakwah menurut Buya Yahya yaitu amar ma'ruf nahi munkar. Pada intinya adalah mengajak umat ke jalan taqwa dan juga memberikan penjelasan tentang yang benar dan salah. 
Seorang da'i saat berdakwah harus mempunyai tujuan, sehingga dapat tercapai apa yang diharapkan dan dakwah itu tidak sia-sia.

Dakwah dilakukan dengan berbagai kegiatan atau aktifitas yang memiliki strategi dan pendekatan yang menarik sehingga dakwah itu menjadi berharga. Kegiatan dakwah itu sendiri tidak hanya dengan berceramah, namun sebenarnya sangatlah luas. Buya Yahya berpendapat, bahwa dakwah itu banyak macamnya. Mengajar itu dakwah, mengisi pengajian-pengajian juga dakwah, membangun dan membina masyarakat juga termasuk dakwah. Jadi, dakwah itu luas, baik itu bersifat formal maupun nonformal.

Metode yang digunakan oleh da'i dalam berdakwah, bisa lebih efektif dan efesien, serta harapan dari sebuah dakwah bisa terealisasi. Metode dakwah yang diterapkan Buya Yahya yaitu metode tabligh, sebagaimana yang dilakukan oleh para Nabi Allah. Tabligh tersebut dilakukan dengan membentuk majelis ceramah. Metode tabligh adalah metode yang dilakukan dengan maksud untuk menyampaikan keterangan, petunjuk, pengertian dan penjelasan tentang suatu masalah dihadapan orang banyak. Sebagaimana penuturan Buya Yahya: "Bahwa metode dakwah yang utama yaitu tabligh, sebagaimana yang dilakukan oleh para Rasul dalam mengajak ummatnya. Karena dakwah itu tidak hanya untuk kelompok tertentu saja, dakwah itu untuk semua ummat, semua masyarakat, baik itu orang kaya maupun orang yang kurang mampu". Metode tabligh sering digunakan Buya Yahya di dalam setiap pengajiannya diberbagai tempat. Seperti mengisi ceramah di pondok pesantren dan dalam kegiatan safari dakwah, seperti di LPD al Bahjah Cirebon, kajian rutin bulanan di Masjid Agung Indramayu, Bogor,
Bandung, Tulungagung, Pekanbaru dan Batam.

Dalam menyampaikan pesan dakwah, metode tabligh adalah metode yang paling utama yang digunakan oleh Buya Yahya dalam setiap pengajiannya. Diaplikasikan lewat beberapa ceramah, seperti ceramah keagamaan (pengajian). Dengan metode tersebut banyak keberhasilan yang didapat, terutama dalam sikap keberagamaan dan kehidupan seharihari. Dalam berceramah, Buya Yahya begitu tenang dan sabar dalam menjelaskan materi dakwah yang diberikan kepada jamaahnya (mad'u). Sehingga jama'ah antusias dalam mendengarkan dakwah yang disampaikannya. Dalam berceramah, Buya Yahya tidak jarang menyelipkan humor, sehingga mad'u tidak jenuh dalam mendengarkan. Sedangkan dalam menerapkan materi, Buya Yahya mengambil rujukan yang paling utama dari al Qur'an dan hadist, lalu dari kitab-kitab, seperti jika menyampaikan materi fiqh merujuk dari kitab madzhab empat, tasawwuf merujuk pada karya al Ghazali. Sehingga mad'u lebih paham dan percaya tentang materi yang disampaikannya. Buya Yahya dalam menggunakan metode tabligh berbeda dengan tabligh yang dilakukan oleh para da'i lainnya. Buya Yahya mengembangkan tabligh tersebut dengan melakukan pengkaderan dengan tarbiyah dari tarbiyah tersebut akan muncul ulama' yang akan melanjutkan misi dakwah ke depannya. Oleh karena itu, Buya Yahya mendirikan Pondok Pesantren Lembaga Pengembangan

Dakwah (LPD) al Bahjah. Sebagaimana penuturan Buya Yahya: "Bahwa banyak orang yang hanya mengandalkan tabligh saja, ceramah ke mana-mana tapi tidak mempunyai kader untuk melanjutkan misi dakwahnya. Saya tidak menyalahkan da'i yang seperti itu, tapi saya meyayangkannya, apabila dia 
mau bekerja lebih keras lagi maka dia akan mempunyai kader yang melanjutkan misi dakwahnya".

Sebenarnya dalam aktivitas tabligh, Buya Yahya sambil menggali potensi untuk mengajak bersama-sama melakukan tabligh. Dalam bertabligh juga menggunakan berbagai media, seperti sound sistem dan media-media lain, seperti radio, TV, live streaming, facebook, instagram, aplikasi android (buya Yahya di playstore) dan web, agar tabligh tersebut sampai ke masyarakat luas. Metode tabligh tersebut dilakukan dengan al hikmah, mauidzah al hasanah dan apabila diperlukan dilanjutkan dengan al mujadalah.

Menurut Buya Yahya, kedudukan metode dalam berdakwah sangat penting, tidak hanya dalam berdakwah, dalam melakukan apapun harus ada metodenya. Tanpa ada metode, suatu pekerjaan akan berjalan apa adanya. Dari metode tersebut akan memunculkan strategi. Dakwah tanpa menggunakan metode, maka dalam dakwah tersebut tidak ada persiapan dan akhirnya tidak ada yang diharapkan, karena tidak ada evaluasi. Buya Yahya menyatakan, orang berdakwah tanpa menggunakan metode itu tidak salah, tapi kebanyakan dakwahnya tidak mengarah. Dakwah sangat penting dalam kehidupan sehari hari. Buya Yahya tidak hanya berdakwah melalui ceramah, namun dalam kehidupan sehari-hari telah mengamalkan nilai-nilai dakwah seperti mengajarkan membaca al Qur'an yang baik kepada calon tahfidz. Dia juga selalu bertutur kata yang sopan dan santun, serta selalu bersikap ramah kepada masyarakat dan santri.

Konsep dakwah yang digunakan sangat variatif, mulai dari isi atau materi sampai dengan metode yang digunakan. Isi atau materi saat berdakwah, tidak hanya pada satu pokok. Seringkali Buya Yahya menyampaikan sesuatu yang sedang hangat dimasyarakat. Serta penyampaian dakwahnya itu penuh dengan ketegasan, sehingga jama'ah tidak merasa bingung. Dengan demikian, dakwah secara luas bukan sebatas majelis ceramah saja, akan tetapi merupakan praktek dalam kehidupan sehari-hari yang mempunyai nilai ajaran Islam kepada orang lain. Oleh karena itu, memberikan contoh kepada orang lain dalam kebaikan, masuk dalam kategori dakwah. Buya Yahya juga menyatakan bahwa, perkembangan dakwah sebenarnya sudah sangat berkembang pesat, terlebih didukung dengan media-media komunikasi yang semakin terbuka untuk menyiarkan agama Islam. Jadi tidak ada alasan bagi seseorang untuk tidak menyampaikan suatu ilmu yang bermanfaat. Jika seseorang tidak mampu melakukan dakwah dengan lisan, maka berpeluang menyampaikan dakwah tersebut melalui media-media yang ada saat ini.

Bagi Buya Yahya, dalam berdakwah tidak ada batasan umur, maka dia ingin berdakwah sampai akhir hayat, karena itu merupakan sebuah kewajiban setiap manusia di muka bumi yang mendapatkan anugerah dari Allah SWT. Dalam berdakwah, yang paling penting adalah kita harus mempertebal kualitas dakwah mulai dari materi-materi dakwah dan pengaplikasian diri dengan apa yang disampaikan kepada mad'u. Menurut Buya Yahya, da'i yang professional adalah da'i yang menganggap bahwa ceramah itu adalah bagian dari diri sendiri dan yang menjadi tanggung jawab moral bagi da'i itu sendiri, bukan untuk kepentingan pribadi. Kegagalan berdakwah itu beragam, dakwah yang disampaikan tidak sama dengan perilaku seorang da'i dan isi dakwah yang disampaikan tidak sesuai dengan kebutuhan mad'u, serta penyampaian dakwah itu sendiri yang kurang bisa diterima oleh mad'u karena da'i tersebut tidak mengetahui karakteris- 
tik mad'u. Apalagi saat seorang da'i mengharapkan imbalan materi dari apa yang disampaikan.

Tabligh yang dilakukan Buya Yahya berbeda dengan tabligh pada umumnya. Setelah tabligh dilakukan, Buya Yahya mengembangkan tabligh tersebut dengan melakukan pengkaderan dengan tarbiyah dari tarbiyah tersebut akan muncul ulama' yang akan melanjutkan misi dakwah ke depannya. Oleh karena itu, Buya Yahya mendirikan Pondok Pesantren Lembaga Pengembangan Dakwah (LPD) al Bahjah. Sebenarnya dalam aktivitas tabligh, Buya Yahya sambal menggali potensi untuk mengajak bersama-sama melakukan tabligh. Dalam bertabligh juga menggunakan berbagai media, seperti sound system dan mediamedia lain, seperti radio, $\mathrm{TV}$, live streaming, facebook, instagram, aplikasi android.

Berdasarkan penjelasan di atas, metode mujadalah yang dipakai oleh Buya Yahya adalah metode tanya jawab (al asilah wal ajwibah). Metode oleh Buya Yahya dilakukan pada saat ceramah dengan cara memberikan waktu kepada mad'u untuk bertanya setelah Buya Yahya menyampaikan pesan dakwah (maddah). Dalam kesempatan yang lain, metode tanya jawab dilakukan dengan mad'u/ jama'ah datang di al Bahjah menemui Buya Yahya yang juga memiliki forum silaturahim para pejuang, yaitu merekamereka yang berkiprah dilembaga LPD alBahjah dan para donatur, Buya Yahya juga menulis buku dengan judul "Indahnya Memahami Perbedaan Para Ulama" dengan tujuan agar dapat bermanfaat untuk umat dalam memecahkan masalah-masalah hilafiayah yang selamaa ini menjadi perbedaan di masyarakat. Sedangkan metode al hiwar (dialog) yang dilakukan Buya sebagai pemecahan sebuah persoalan, baik antara Buya Yahya dengan mad'u atau Buya
Yahya dengan para cendekiawan, da'i yang lain .dilakukan dalam bentuk forum diskusi atau seminar.

Menurut Buya Yahya, kedudukan metode dalam berdakwah sangat penting, tidak hanya dalam berdakwah. Tanpa ada metode, suatu pekerjaan akan berjalan apa adanya. Dari metode tersebut akan memunculkan strategi. Dakwah tanpa menggunakan metode, maka dalam dakwah tersebut tidak ada persiapan dan akhirnya tidak ada yang diharapkan, karena tidak ada evaluasi. Buya Yahya menyatakan, orang berdakwah tanpa menggunakan metode itu tidak salah, tapi kebanyakan dakwahnya tidak mengarah. Buya Yahya juga menyatakan bahwa, perkembangan dakwah sebenarnya sudah sangat berkembang pesat, terlebih didukung dengan media-media komunikasi yang semakin terbuka untuk menyiarkan agama Islam. Jadi tidak ada alasan bagi seseorang untuk tidak menyampaikan suatu ilmu yang bermanfaat. Jika seseorang tidak mampu melakukan dakwah dengan lisan, maka berpeluang menyampaikan dakwah tersebut melalui media-media yang ada saat ini.

Menurut penulis, Buya Yahya telah memberikan teladan yang baik kepada mad'u dan santri, yang dapat terlihat dari pengalaman pribadi peneliti, bahwa pada saat tiba waktu shalat, beliau menyuruh santrinya berjamaah dan itu juga yang beliau contohkan dalam berjamaah disetiap harinya dalam shalat lima waktu. Tidak hanya itu, ketika beliau menyebutkan haram kepada jemaah terhadap sesuatu yang diharamkan oleh al Qur'an, seperti memakan barang hasil curian dan sebagainya, beliaupun mencontohkan tidak sama sekali memakan makanan hasil curian. Dengan demikian, ketika da'i mengajak orang lain untuk melakukan kebaikan sementara da'i juga harus mencontohkannya kepada mad'u, 
maka mad'u akan menerima dan mengikutinya. Oleh karena itu, nasihat atau pesan beliau untuk da'i-da'i yang mau mengharapkan kesuksesan dalam berdakwah adalah seorang da'i harus ikhlas dalam berdakwah dan mau belajar untuk memperdalam agar dakwah itu menjadi sangat berharga.

Buya Yahya selain menggunakan metode tabligh juga memiliki cara lain yaitu dengan memberi layanan travel biro haji, BMT syariah, PPOB dan infaq barang bekas. Dengan tujuan untuk memfasilitasi umat dalam perbankkan dengan sistem syariah dan menyelamatkan ketergantungan umat Islam terhadap bank non-Islam (konvensional) yang menyebabkan umat islam berada di bawah kekuasaan bank Konvensional. Infaq barang bekas dengan tujuan agar mad'u tertarik atau mengikat untuk mengikuti majelis dakwah Buya Yahya, karena bagi Buya Yahya umat berinfaq dengan barang bekas itu merupakan infaq yang paling ikhlas yang umat berikan.

\section{SIMPULAN}

Buya Yahya merupakan kyai yang menguasai berbagai macam disiplin ilmu, diantaranya ilmu fiqh, aqidah, ilmu al Qur'an, ilmu hadits, ilmu nahwu, ilmu sharaf, dan lain-lain. Dalam berdakwah beliau menyampaikan materi dakwah sesuai dengan kondisi masyarakat sekarang, tetapi tidak bertentangan dengan al Qur'an dan hadits, agar dakwahnya menjadi aktual, faktual dan kontekstual. Dari pembahasan di atas penulis menyimpulkan bahwa KH. Yahya Zainul Ma'arif terbilang da'i yang profesional. Hal ini terlihat dari apa yang disampaikan beliau, menjadi suatu kebutuhan mad'u dan profesionalismenya terlihat dalam perencanaan dakwahnya, atau yang disebut dengan strategi dakwah. 
DAFTAR PUSTAKA

Abdullah, Dzikron, Metodologi Dakwah, Semarang: Fakultas Dakwah IAIN Walisongo, 1980.

Achmad, Amrullah, Dakwah Islam dan Perubahan Sosial, Yogyakarta: Primaduta, 1983

Al Haddad, Said Abdullah Bin Alwi, 2001, Kesempurnaan dan Kemulian Dakwah Islam, Bandung: Pustaka Setia.

Al Nabiry, Fathul Bahri, 2008, Meniti Jalan Dakwah: Bekal Perjuangan Para Da'i, Jakarta: Amzah.

Amin, Samsul Munir, Rekontruksi Dakwah Islam, Jakarta: Sinar Grafika Offset, 2008.

Anshari, Hafi, Pemahaman dan Pengamatan Dakwah, Surabaya, Al-Ikhlas, 1993.

Ardani, Moh., 2006, Memahami Permasalahan Fiqh Dakwah, Jakarta: Mitra Cahaya Utama.

Arikunto, Suharsimi, 2002, Prosedur Penelitian Suatu Pendekatan Praktek, Jakarta: Rineka Cipta.

Aziz, Mohammad Ali, 2006, Ilmu Dakwah, Jakarta: Kencana.

Bachtiar, Wardi, 1997, Metodologi Penelitian Ilmu Dakwah, Jakarta: Logos.

Bungin, Burhan, 2003, Analisis Data Penelitian Kualitatif, Pemahaman Filisofis dan Metodologis ke Arah Penguasaan Model Aplikasi. Jakarta: Raja Grafindo Persada.

Danandjaja, J. 1988, Antropologi Psikologi: Teori, Metode dan Sejarah Perkembangannya. Jakarta: Rajawali Press.

Danim, Sudarwan, 2002, Menjadi Peneliti Kualitatif: Ancangan Metodologi, Presentasi, dan Publikasi Hasil Penelitian untuk Mahasiswa dan Peneliti Pemula Bidang IlmuIlmu Sosial, Pendidikan, dan
Humaniora. Bandung: Pustaka Setia.

Daulay, Hamdun, 2001, Dakwah di Tengah Persoalan Budaya dan Politik, Yogyakarta: Lesfi.

Depag RI, 1993, al Qur'an dan Terjemahnya, Semarang: al Wa'ah. Rafudin, Maman Abdul Djaliel, Prinsip dan Stategi Dakwah, Jakarta: Pustaka Setia, 1997.

Enjang AS. dan Aliyuddin, 2009, DasarDasar Ilmu Dakwah Pendekatan Filosofis dan Praktis, Bandung: Widya Padjadjaran. Furchan, Arief, 2005, Metode Penelitian Mengenal Study Tokoh, Yogyakarta: Pustaka Pelajar.

Hadi, Sutrisno, 1996, Metodologi Reseach. Yogyakarta: Yayasan Penerbit Fakultas Psycologi Universitas Gajah Mada.

Hafidhuddin, Didin, Dakwah Aktual, Jakarta: Gema Insani Press, 2000.

Hamka, 1990, Prinsip dan Kebijaksanaan Dakwah Islam, Jakarta: Pustaka Panjimas.

Harahap, Syahrin, 2011, Metodologi Studi Tokoh Pemikiran Islam. Jakarta: Prenada Media Group.

Iskandar, 2009, Metodologi Penelitian Kualitatif, Jakarta: Gang Persada. Juliet, Corbin dan Anselm Strauss, 2003, Dasar-Dasar Penelitian Kualitatif, Yogyakarta: Pustaka Pelajar.

Ma'arif, Ahmad Syafi'i dan Sahid Tuhu Leley (ed), 1990, Alqur'an dan Tantangan Modernisasi, Yogyakarta: Sipres.

Mansur, Mustofa, Teladan di Medan Dakwah, Solo: Era Intermedia, 2000.

Moleong, Lexy J., 2010, Metodologi Penelitian Kualitatif, Bandung: Remaja Rosda Karya. 
Munawwir, M. Warson, 1994, Kamus al Munawwir, Surabaya: Pustaka Progresif.

Munir, M \& Wahyu Illahi. 2006. Manajemen Dakwah. Jakarta: Rahmat Semesta.

Munir, Muhammad, Metode Dakwah, Jakarta: Kencana, 2009.

Omar, Toha Yahya, 2004, Ilmu Dakwah, Jakarta: Wijaya.

Pimay, Awaludin, 2006, Metodologi Dakwah. Semarang: Rasail.

Pimay, Awaluddin, 2005, Paradigma Dakwah Humanis, Semarang: Rasail.

Quraish Shihab, 1997, Wawasan al Qur'an, Bandung: Mizan

Rais, Amien, 1999, Cakrawala Islam Antara Cita dan Fakta, Bandung: Mizan.

Sanwar, 1985 Pengantar Studi Ilmu Dakwah. Semarang: Fakultas Dakwah IAIN Walisongo.

Saputra, Wahidin, 2011, Pengantar Ilmu Dakwah, Jakarta : Raja Wali Press.

Saifudin, Azwar. 2001. Metode Penelitian. Yogyakarta: Pustaka pelajar.

Sasono, Adi Sasono, Solusi Islam atas Problematika Umat Ekonomi,
Pendidikan dan Dakwah, Jakarta : Gema Insani Press, 1998

Sugiyono, 2012, Memahami Penelitian Kualitatif. Bandung: Alfabeta.

Sulthon, Muhammad, 2003, Desain Ilmu Dakwah Kajian Ontologis, Epistemologis dan Aksiologis, Yogyakarta: Pustaka Pelajar.

Suparta, Munzier dan Harjani Hefni, 2003, Metode Dakwah, Jakarta: Kencana. Suryabrata, Sumardi, 1998, Metodologi Penelitian, Jakarta: Raja Grafindo Persada, Cet. Ke II.

Syukir, Asmuni, 1983, Dasar-Dasar Strategi Dakwah, Surabaya: al Ikhlas Dokumentasi Profil K.H. Yahya Zainul Ma'arif di LPD AlBahjah Cirebon.

Tim Penyusun Kamus Pusat Bahasa, Kamus Besar Bahasa Indonesia, 2006, Jakarta: Balai Pustaka.

Wawancara dengan KH. Buya Yahya Zainul Ma'arif.

Wawancara dengan Kang Romli selaku Pengurus LPD al Bahjah Cirebon.

www.albahjah.org

www.buyayahya.org 